\title{
Terroryzm a konkurencyjność polskiego handlu zagranicznego z krajami Unii Europejskiej
}

\author{
Ewa Szymanik
}

\begin{tabular}{|c|c|}
\hline & A B S T R A K T \\
\hline $\begin{array}{l}\text { Cel artykułu: Cele } \\
\text { kurencyjność han } \\
\text { ropejskiej, w któr }\end{array}$ & $\begin{array}{l}\text { m tego artykułu jest ukazanie, czy i jak terroryzm wpływa na kon- } \\
\text { dlu zagranicznego, na przykładzie wymiany Polski z krajami Unii Eu- } \\
\text { ych w ostatnim dziesięcioleciu doszło do zamachów. }\end{array}$ \\
\hline $\begin{array}{l}\text { Metodyka badań: } \\
\text { ności. Artykuł ana } \\
\text { kurencyjności gos } \\
\text { Zbadano, czy zam } \\
\text { handlu Polski z kr }\end{array}$ & $\begin{array}{l}\text { Jako główną metodę zastosowano analizę wskaźników konkurencyj- } \\
\text { lizuje przy pomocy wskaźników RCA i IIT potencjalne skutki dla kon- } \\
\text { podarek, ze szczególnym uwzględnieniem państw Unii Europejskiej. } \\
\text { lachy terrorystyczne w Unii wpłynęły na zmianę konkurencyjności } \\
\text { ajami nimi dotkniętymi. }\end{array}$ \\
\hline $\begin{array}{l}\text { Wyniki: Na podst } \\
\text { w dłuższym okres } \\
\text { zależy od ich ogól } \\
\text { Polski zależność t }\end{array}$ & $\begin{array}{l}\text { awie osiągniętych wyników można stwierdzić, że choć terroryzm } \\
\text { ie wpływa na konkurencyjność gospodarek, to jednak siła wpływu } \\
\text { nej kondycji i stopnia rozwoju systemu zabezpieczeń, a w przypadku } \\
\text { nie jest silnie widoczna. }\end{array}$ \\
\hline $\begin{array}{l}\text { Wkład i wartość c } \\
\text { torska analiza sku }\end{array}$ & $\begin{array}{l}\text { odana: Wartością dodaną artykułu jest obliczenie wskaźników, au- } \\
\text { tków terroryzmu w nowym kontekście. }\end{array}$ \\
\hline Typ artykułu: & oryginalny artykuł badawczy \\
\hline Słowa kluczowe: & $\begin{array}{l}\text { terroryzm; konkurencyjność; Unia Europejska; polski handel zagra- } \\
\text { niczny; eksport }\end{array}$ \\
\hline Kody JEL: & $\mathrm{E} 23, \mathrm{E} 60, \mathrm{~F} 10, \mathrm{~F} 23, \mathrm{H} 56$ \\
\hline Artykuł nadesł & Artykuł zaakceptowano: 1 czerwca 2019 \\
\hline
\end{tabular}

\section{Sugerowane cytowanie:}

Szymanik, E. (2019). Terroryzm a konkurencyjność polskiego handlu zagranicznego z krajami Unii Europejskiej. International Entrepreneurship Review (previously published as International Entrepreneurship | Przedsiębiorczość Międzynarodowa), 5(1), 57-75. https://doi.org/10.15678/IER.2019.0501.04

\section{WPROWADZENIE}

Zmiany zachodzące na świecie i w gospodarkach zaowocowały nie tylko pożytecznymi skutkami w postaci rozwoju. Pojawiły się też zachowania niepożądane, takie jak terroryzm.

Nie jest to zjawisko nowe. Można zauważyć, że od początku kształtowania się struktur państwowych, czy szerzej - władzy, ludzkość stykała się z różnego rodzaju przemocą wobec poszczególnych osób. Najbardziej znane były oczywiście zamachy na życie władców (na przykład Juliusza Cezara), lecz dotyczyło to także ludzi o mniejszych wpływach, takich 
jak szeroko rozumiani właściciele (nie tylko ziemscy) czy dowódcy wojskowi. Wszystkie miały mniej lub bardziej znaczące skutki dla historii czy gospodarki danego regionu, aczkolwiek nie wszystkie można byłoby dziś określić mianem terrorystycznych. $U$ ich podstawy leżały przede wszystkim nierozwiązane problemy społeczne.

Świadomość, że terroryzm ma znaczący wpływ na gospodarkę, nie jest powszechna. Organizacje terrorystyczne posługują się najnowocześniejszą techniką i stosują niekonwencjonalne sposoby walki. Potrzebują do tego dużych środków finansowych z wielu źródeł, także nietypowych. Wszystko zaś, co podlega prawom popytu i podaży, niezależnie od stopnia legalności, tworzy rynek i wpływa na szeroko rozumiany system gospodarczy.

Terroryzm to różnie umotywowane działania podjęte w celu wymuszenia od władz i społeczeństw określonych zachowań, realizowane z całą bezwzględnością, za pomocą różnych środków, w warunkach celowo nadanego rozgłosu i specjalnie wywołanego lęku (Nowa encyklopedia powszechna, 1997). Inna definicja mówi, że jest to forma przemocy politycznej, która polega na stosowaniu morderstw lub zniszczenia (albo zagrożeniem stosowania takich środków) w celu wywołania szoku i ekstremalnego zastraszenia jednostek, grup, społeczeństw lub rządów, czego efektem mają być wymuszenia pożądanych ustępstw politycznych, sprowokowanie nieprzemyślanych działań i/lub zademonstrowanie/nagłośnienie politycznych przekonań (Bolechów, 2003). Początkowo zarówno skala, jak i społeczny oddźwięk zamachów były dość skromne, aczkolwiek nie zawsze - sztandarowym przykładem zamachu o skutkach światowych było zabicie arcyksięcia Ferdynanda w Sarajewie 28 czerwca 1914 r., co stało się bezpośrednią przyczyną wybuchu I wojny światowej.

Znaczące zmiany nastąpiły pod koniec XX w. Zmieniła się zarówno struktura organizacji terrorystycznych, jak i formy ich działalności. Celem pośrednim stało się zastraszenie i zabicie nie pojedynczych osób, lecz jak największej ich liczby, a bezpośrednim - i to nie zmieniło się od wieków - zaspokojenie własnych, najrozmaitszych potrzeb. Pojawiła się między innymi interferencyjna koncepcja terroryzmu, zakładająca, że istnieje wiele i różnorodnych powiązań pomiędzy wewnętrznymi (państwowymi) a międzynarodowymi aspektami omawianego zagadnienia (Wojciechowski, 2011).

Najczęściej chodzi o osiągnięcie wpływu na decyzje socjalne, polityczne i militarne, by przyniosły one określone korzyści żądającym. Często terroryzm jest skutkiem biedy, poczucia wykluczenia lub niesprawiedliwości i bezsilności (Cegiełka, 2015) Mimo tego jest wielkim zagrożeniem dla bezpieczeństwa, wartości wyznawanych przez społeczeństwa demokratyczne oraz praw i wolności obywateli, szczególnie wówczas, gdy dotyka przypadkowych, niewinnych osób. Zatem w żadnym wypadku nie można go usprawiedliwić (Rada Europejska, 2005).

Celem tego artykułu jest ukazanie, czy i jak terroryzm wpływa na konkurencyjność handlu zagranicznego, na przykładzie wymiany Polski z krajami Unii Europejskiej, w których w ostatnim dziesięcioleciu doszło do zamachów. Zastosowane metody to głównie analiza danych statystycznych i najpopularniejszych wskaźników pomiaru konkurencyjności, takich jak RCA, liczony metodą logarytmiczną, i IIT, wskaźnik wymiany wewnątrzgałęziowej.

\section{PRZEGLĄD LITERATURY}

Ponieważ na omawiany temat składa się kilka zagadnień, główny przegląd literatury został dokonany w tekście, tym bardziej, że najbogatsza dotyczy związków pomiędzy atakami terrorystycznymi a wahaniami na giełdzie, a ten problem nie jest badany w niniejszej 
pracy. Dostępna literatura, wbrew tytułom, zajmuje się głównie problemem terroryzmu, w niewielkim stopniu uwzględniając jego wpływ na gospodarkę. Badania prowadzone przez autorów artykułów dotyczą przede wszystkim poszczególnych jej części, na przykład wyżej wspomnianej giełdy (Tavor, 2014), turystyki (Michalczuk-Ouerghi i Dłużewska, 2018), gospodarki morskiej (Łuczkowska, 2013) czy rolnictwa (Kacperska, 2017). Przykładem badań obejmujących całą gospodarkę są prace Abadiego i Gardeazabala (2005) czy Golda (2003). Berman (2009) skupił się głównie na korzyściach, jakie odnoszą terroryści i ich organizacje i coraz więcej autorów kieruje swe zainteresowania w tę stronę, brak zaś prac badających wpływ terroryzmu na konkurencyjność gospodarek.

\section{Geneza współczesnego terroryzmu}

Jak już wspomniano, terroryzm jest znany od dawna. Do świadomości ogółu to zagrożenie przeniknęło jednak dopiero 11 września 2001 r., po zamachu na World Trade Center. Stało się wówczas jasne, że zagrożenie może dotyczyć każdego. Po tym zamachu światowa opinia publiczna skierowała uwagę na związki historyczne między islamem a terroryzmem, co mimo częstego powoływania się zamachowców na cytaty z Koranu jest dużym uproszczeniem, gdyż Koran nie usprawiedliwia zamachów, wyraźnie zakazując zabijania osób niezdolnych do walki, zwierząt, niszczenia przyrody, zatruwania studni, bezczeszczenia zwłok i samobójstw (Koran, 1986).

Warto też pamiętać, że terroryzm kryjący się za motywami religijnymi to tylko jedna z jego istniejących form. Może on również być usprawiedliwiany względami politycznymi czy koniecznością życiową (na przykład znany z ideologii hitlerowskiej Lebensraum - przestrzeń życiowa, czy też czystość rasowa). Ważny jest program ideologiczny, motywujący do działania i będący elementem utrzymującym trwałość grupy. O tym, jak złożonym zjawiskiem jest terroryzm, mówi fakt, że funkcjonuje ponad dwieście jego definicji (Fiszer, 2012).

Wszystkie działania terrorystów są zaplanowane i mają jasny cel. Następujące po akcie terroru bezład i chaos sprawiają wrażenie, ze ataku dokonał przypadkowy szaleniec, a cel również wybrano przypadkowo. Przyciąga to uwagę mediów, a to właśnie jest celem aktów przemocy. Należy też zauważyć, że sprawcy przyznają się niemal natychmiast (Cegiełka, 2015).

Jak wspomniano wyżej, pod koniec XX w. terroryzm znacznie się zmienił, do tego stopnia, że mówi się o nowym modelu. Zdaniem Howarda (2002) różnice są następujące:

- nowy terroryzm jest bardziej zabójczy - oprócz przyciągnięcia uwagi celem jest zabójstwo jak największej liczby ludzi,

- istnieją grupy transnarodowe, o międzynarodowym zasięgu działania,

- dobre finansowanie organizacji ze źródeł zarówno legalnych, jak i nielegalnych,

- samodzielność grup i ich niezależność od państwowych sponsorów (co miało miejsce w przypadku terroru usankcjonowanego przez państwo, na przykład w hitlerowskich Niemczech),

- lepsze wykształcenie, wyposażenie i wyszkolenie terrorystów, ich większa determinacja i profesjonalizm,

- grupy są trudniejsze do infiltrowania z uwagi na ich specyfikę kulturową i ideologiczną, z przewagą motywacji religijnej,

- terroryści mają łatwiejszy dostęp i wiedzę o broni masowego rażenia. 
Rozwój cywilizacyjny, postęp naukowo-techniczny oraz nowa sytuacja geopolityczna na świecie sprawiają, że zmieniają się formy i środki działania terrorystów. Obecnie są one podobne do działań partyzanckich, dlatego też terroryści określani są mianem „partyzantów”, czy „zielonych ludzików” (jak separatyści na Ukrainie). Korzystają z najnowocześniejszych osiągnięć techniki i są w stanie prowadzić walkę z regularnymi oddziałami wojskowymi. Dlatego też tego typu działania zostały określone mianem wojny hybrydowej, która jest kombinacją działań regularnych i nieregularnych sił zbrojnych, elementów kryminalnych, organizacji politycznych oraz terrorystycznych, stosujących tradycyjną i nietradycyjną walkę (Nowacki, 2015).

W tabeli 1 przedstawiono największe organizacje terrorystyczne na świecie.

Tabela 1. Światowe organizacje terrorystyczne

\begin{tabular}{|l|l|l|}
\hline \multicolumn{1}{|c|}{ Nazwa } & \multicolumn{1}{c|}{ Obszar działania } & \multicolumn{1}{c|}{ Taktyki } \\
\hline $\begin{array}{l}\text { Tzw. Państwo Islamskie Iraku i } \\
\text { Lewantu (ISIL, ISIS, lub Daesh) }\end{array}$ & $\begin{array}{l}\text { Azja i Pacyfik, Europa, Rosja, Środ- } \\
\text { kowy Wschód i północna Afryka }\end{array}$ & $\begin{array}{l}\text { Zamachy bombowe, branie } \\
\text { zakładników, zabójstwa }\end{array}$ \\
\hline Taliban & Afganistan, Pakistan & Zamachy bombowe \\
\hline Al-Shabaab & Somalia, wschodnia Afryka & Zamachy bombowe \\
\hline Boko Haram & Nigeria, Czad, Kamerun, Niger & $\begin{array}{l}\text { Zamachy bombowe, branie za- } \\
\text { kładników, ataki samobójcze }\end{array}$ \\
\hline
\end{tabular}

Źródło: (Institute for Economics \& Peace, 2018a, s. 15-17).

Z powyższych informacji wynika, że najszerszy teren obejmują działania ISIS, którego wpływy rozciągają się poza kraje islamskie, czego dowodem były ataki z 2001 r. w USA i 2004 r. w Hiszpanii.

ISIS wciąż uchodziło za najbardziej krwawą grupę terrorystyczną na świecie w 2017 r. Zmniejszenie liczebności ugrupowania znalazło swe odbicie w poziomie aktywności terrorystycznej w Europie; liczba zabitych spadła o 75\%, z 827 w 2016 r. do 204 w 2017 r. Wstępne dane z 2018 r. sugerują kontynuację tego trendu, gdyż w okresie styczeń - październik 2018 r. odnotowano w Europie Zachodniej mniej niż 10 osób zabitych na skutek ataków. Krajem, w którym w 2017 r. zabito największą liczbę osób, był Afganistan. Liczba ofiar była w przybliżeniu równa tej z poprzedniego roku (Institute for Economic \& Peace, 2018a).

\section{Ekonomiczne skutki terroryzmu}

Na wpływ zamachów na gospodarkę zaczęto zwracać uwagę po 2001 r. i atakach na World Trade Center. Ich efektem był spadek tempa wzrostu gospodarczego w USA, choć w kolejnych latach straty były nadrabiane. Nie należy jednak zapominać, że skutków zamachu obawiały się także kraje, które sprzedawały swe produkty do Ameryki, zwłaszcza Niemcy, Japonia, Korea Południowa, Singapur i Tajwan, gdyż amerykańska konsumpcja stanowiła pod koniec XX w. siłę napędową międzynarodowego handlu, odpowiadając za 15\% światowego PKB. Zdaniem B. Pawłowskiego, cytowanym w tym samym źródle, pośrednim skutkiem zamachów było zmniejszenie światowego PKB o 1,7\%, zniknięcie $9 \mathrm{mln}$ miejsc pracy (w tym w samych Stanach 1,1 mln) (Cegiełka, 2015).

W tabeli 2 przedstawiono rozmieszczenie ataków terrorystycznych w ostatnim dziesięcioleciu. Podzielono je według regionów. Podział kontynentalny nie do końca jest adekwatny, gdyż zarówno Azja, jak i Afryka są zbyt zróżnicowane kulturowo, religijnie i gospodarczo, by można je było traktować jako całość. Zróżnicowanie panuje też w Europie 
- jej wschodnia część jest mniej narażona, przynajmniej na razie. Z uwagi na, z jednej strony, procesy integracyjne, a z drugiej - postępujący radykalizm i narastającą ksenofobię, a także zagrożenie wojenne (możliwe szersze konsekwencje wojny rosyjsko ukraińskiej), należy oczekiwać zwiększenia zagrożenia także w krajach uchodzących do tej pory za dość bezpieczne, w tym również w Polsce.

Tabela 2. Ataki terrorystyczne i ich rozmieszczenie

\begin{tabular}{|l|c|c|c|c|c|c|c|c|c|c|}
\hline \multicolumn{1}{|c|}{ Region } & $\mathbf{2 0 0 8}$ & $\mathbf{2 0 0 9}$ & $\mathbf{2 0 1 0}$ & $\mathbf{2 0 1 1}$ & $\mathbf{2 0 1 2}$ & $\mathbf{2 0 1 3}$ & $\mathbf{2 0 1 4}$ & $\mathbf{2 0 1 5}$ & $\mathbf{2 0 1 6}$ & $\mathbf{2 0 1 7}$ \\
\hline Ogółem & 4797 & 4712 & 4789 & 5018 & $\mathbf{8 5 2 2}$ & 12036 & 16903 & 14965 & 13587 & 10900 \\
\hline Europa & 371 & 346 & 392 & 290 & 366 & 426 & 1177 & 1017 & 253 & 401 \\
\hline $\begin{array}{l}\text { Środkowy Wschód } \\
\text { i północna Afryka }\end{array}$ & 1534 & 1357 & 1457 & 1654 & 2409 & 4560 & 6939 & 6036 & 6115 & 3780 \\
\hline Południowa Azja & 1754 & 1943 & 1964 & 2107 & 3803 & 4612 & 4998 & 4585 & 3639 & 3430 \\
\hline $\begin{array}{l}\text { Azja Południowo- } \\
\text { Wschodnia }\end{array}$ & 514 & 560 & 472 & 353 & 587 & 1188 & 1082 & 1072 & 1077 & 1020 \\
\hline Afryka Subsaharyjska & 380 & 283 & 323 & 482 & 1168 & 999 & 2321 & 1964 & 2077 & 1970 \\
\hline Ameryka Poludniowa & 144 & 158 & 148 & 106 & 133 & 182 & 283 & 176 & 159 & 172 \\
\hline Ameryka Pólnocna & 31 & 16 & 21 & 12 & 39 & 32 & 37 & 62 & 75 & 97 \\
\hline Australia i Oceania & 8 & 1 & 1 & 0 & 0 & 1 & 9 & 14 & 10 & 12 \\
\hline Środkowa Azja & 36 & 31 & 9 & 9 & 12 & 7 & 9 & 10 & 17 & 7 \\
\hline Wschodnia Azja & 25 & 8 & 1 & 4 & 4 & 15 & 43 & 28 & 8 & 7 \\
\hline $\begin{array}{l}\text { Ameryka Środkowa } \\
\text { i Karaiby }\end{array}$ & 0 & 9 & 1 & 1 & 1 & 14 & 5 & 1 & 3 & 4 \\
\hline
\end{tabular}

Źródło: opracowanie własne na podstawie (National Consortium for the Study of Terrorism and Responses to Terrorism, database; National Consortium for the Study of Terrorism and Responses to Terrorism, 2017, s.2).

Z danych w tabeli wynika, że terroryści znacząco wzmogli swą aktywność od roku 2012, czyli od zakończenia kryzysu. Można byłoby wysnuć stąd nieco przewrotny wniosek, że wcześniej ludzie należący do takich ugrupowań byli zajęci codzienna walką o byt, a w momencie, gdy sytuacja gospodarcza zaczęła się poprawiać, pomyśleli o „rozrywkach”. Oczywiście nie jest to wniosek naukowy. Prawdziwym wytłumaczeniem tego faktu może być co innego - po kryzysie sytuacja się zmieniła i wiele osób nie odzyskało dawnego statusu materialnego, co zrodziło większą frustrację. Poza tym, być może, lata kryzysu były czasem gromadzenia broni za stosunkowo niższą cenę, a strategia nasilenia ataków w momencie, gdy sytuacja gospodarcza zaczęła się poprawiać i wzrost dobrobytu spowodował zwiększenie poczucia bezpieczeństwa społecznego, była zaplanowana.

Europa była regionem o największej poprawie bezpieczeństwa i odnotowała znaczący spadek aktywności terrorystycznej, pomimo zagrożenia, jakim są ukryci radykałowie wśród uchodźców i radykalizacja aktywności online. Liczba zabitych w Europie Zachodniej spadła ze 168 w 2016 r. do 81 w 2017 r. Turcja, Francja, Belgia i Niemcy odnotowały największy spadek, a jedynie Wielka Brytania, Hiszpania, Szwecja i Finlandia zarejestrowały wzrost. Pomimo spadku liczby zabitych ilość zamachów terrorystycznych w Europie wzrosła do 282 z 253 w poprzednim roku. Ponadto 8 krajów zachodnioeuropejskich odnotowało przynajmniej po jednej ofierze śmiertelnej terrorystów w 2017 r, co jest największą liczbą w ciągu ostatnich 20 lat. Spadająca śmiercionośność ataków terrorystycznych w Europie Zachodniej wskazuje, że zdolność ISIS do planowania i koordynacji ataków na wielką skalę została ograniczona i że skutkują procedury przeciwdziałające terroryzmowi, przynajmniej 
w krótkim okresie. Chociaż całkowita liczba ofiar śmiertelnych spadła, wpływ skutków ataków się rozszerza. W 2017 r. w 67 krajach zmarła przynajmniej jedna osoba, co jest drugą pod względem wielkości liczbą w ciągu ostatnich 20 lat. Jest to jednak mniejsza liczba niż w 2016 r., kiedy tych krajów było 79 (Institute for Economic \& Peace, 2018a).

W 2017 r. w 19 krajach odnotowano ponad 100 ofiar śmiertelnych, a w 5 ponad tysiąc. Światowy ekonomiczny wpływ terroryzmu (wydatki na walkę z nim) wyniósł w 2017 r. 52 mld USD, o 42\% mniej niż w roku poprzednim. Należy odnotować, że oceny terroryzmu są konserwatywne, ponieważ nie odnotowują bezpośredniego wpływu na interesy, inwestycje i koszty związane $z$ działaniem agencji bezpieczeństwa zapobiegających zamachom. Terroryzm ma także szerokie konsekwencje ekonomiczne, które mogą się potencjalnie szybko rozszerzyć na globalną gospodarkę ze znaczącymi odgałęzieniami socjalnymi.

Terroryzmowi sprzyjają również konflikty wewnętrzne i zewnętrzne. 10 krajów o najwyższym wskaźniku terroryzmu w świecie jest zaangażowanych przynajmniej w jeden konflikt. W tych krajach odnotowano aż 84\% wszystkich śmiertelnych ofiar w 2017 r. W krajach wysoko rozwiniętych ekonomicznie silnie związane z wpływem terroryzmu są inne czynniki niż konflikty i przestrzeganie praw człowieka. Należą do nich przede wszystkim wykluczenie socjalne i brak szans ekonomicznych. Rosnąca liczba dowodów wskazuje, że w Europie Zachodniej (ale nie tylko) ludzie z przeszłością kryminalną mogą być szczególnie podatni na wpływ grup ekstremistycznych, radykalizację i rekrutację do grup terrorystycznych. Wiele badań wskazuje, że ponad $40 \%$ obcokrajowców walczących w szeregach terrorystów i aresztowanych za taką działalność ma za sobą kryminalną przeszłość.

Chociaż w ciągu ostatnich 3 lat odnotowano spadek wpływu terroryzmu, są obszary, na których oczekiwany jest jego wzrost. Załamanie wpływu ISIS w Syrii i Iraku przeniosło aktywność tych grup w inne miejsca, szczególnie do Maghrebu i Sahelu, głównie do Libii, Nigru i Mali, oraz do południowo-wschodniej Azji, zwłaszcza na Filipiny (Institute for Economic \& Peace, 2018a).

Od dawna wielkim problemem jest terroryzm morski. Utrudnia on handel między krajami zarówno przez zwiększenie zagrożenia dla obiektów portowych (ich zniszczenie przynosi ogromne straty gospodarcze (Szubrycht i Rokiciński, 2006)), jak i przez stwarzanie zagrożenia dla załóg, co oznacza, że mniej statków decyduje się na pływanie w niebezpiecznych rejonach, przez co spadają obroty handlowe lub (jeśli kapitan decyduje się na przepływ dłuższą trasą) rosną koszty transportu, a co za tym idzie - ceny. Nie zawsze taki handel jest opłacalny, więc następuje jego redukcja.

Ekonomiczny efekt skutków terroryzmu wzrósł o 13\% w 2017 r. w porównaniu z rokiem poprzednim, przynosząc stratę 161 mld USD. Jednakże, z wyjątkiem Iraku, globalny wpływ terroryzmu spadł o 22\%, podobnie jak liczba dotkniętych nim krajów. Akty przemocy miały miejsce w 2017 r. w 67 krajach świata, podczas gdy w 2016 r. było to 77 państw (65 w 2015 r.). Największy wzrost ekonomicznego wpływu terroryzmu w stosunku rocznym dotyczy Europy, gdzie nastąpił wzrost kosztów o 76\% w 2017 r., zaś w Ameryce Północnej te koszty wzrosły o 64\% w tym samym okresie (Institute for Economic \& Peace, 2018b).

Zmiany wartości ekonomicznego wpływu terroryzmu przedstawia tabela 3.

Do kosztów terroryzmu w niniejszym wskaźniku zalicza się koszty zabitych i rannych w czasie ataków. Model ekonomicznego wskaźnika przemocy IEP (Institute for Economics and Peace) wyłącza zniszczenie własności i szersze ekonomiczne wpływy terroryzmu, Koszty ekonomiczne ataków są uwzględniane we wskaźnikach strat PKB. 
Tabela 3. Ekonomiczny wpływ terroryzmu według IEP ( $w$ mld USD, ceny stałe z 2017 r.)

\begin{tabular}{|r|c|c|c|c|c|c|c|c|c|}
\hline rok & 2000 & 2001 & 2002 & 2003 & 2004 & 2005 & 2006 & 2007 & 2008 \\
\hline wartość & 9 & $11^{*}$ & 13 & 10 & 20 & 20 & 27 & 43 & 32 \\
\hline rok & 2009 & 2010 & 2011 & 2012 & 2013 & 2014 & 2015 & 2016 & 2017 \\
\hline wartość & 33 & 27 & 28 & 48 & 76 & 108 & 91 & 89 & 52 \\
\hline
\end{tabular}

* po 11.09.2001 r. wartość wskaźnika wyniosła 65

Źródło: (Institute for Economic \& Peace, 2018a, s. 29).

Obszarów gospodarki, które są najbardziej wrażliwe na zamachy, jest kilka. Jako pierwszą należy wymienić turystykę, z której wpływy często stanowią znaczącą część PKB wielu krajów. Spadek bezpieczeństwa i strach przed podróżami odstrasza turystów i powoduje znaczące skutki gospodarcze. Jako przykład można podać Sri Lankę, w której sektor usług tworzy 62\% PKB (Ministerstwo Przedsiębiorczości i Technologii, 2019) (sama turystyka około 5\%), a na której po zamachach z 21 kwietnia 2019 r. zmniejszyła się ilość przyjazdów turystycznych. Według informacji podanych przez „Rzeczpospolitą” z 22 kwietnia 2019 r. liczba odwołanych rezerwacji sięgnęła 20\% (Walewska, 2019).

Kolejną dziedziną gospodarki, na którą terroryzm silnie wpływa, jest sektor zbrojeniowy. Wynika to stąd, że państwa stające w obliczu powtarzających się ataków terrorystycznych przeważnie zwiększają swoje wydatki na ochronę i zbrojenia. Wiąże się to ze wzrostem podatków lub zwiększeniem zadłużenia państwa (Cegiełka, 2015), a w każdym przypadku oznacza przekierowanie środków, które można byłoby przeznaczyć na rozwój gospodarczy w innych dziedzinach.

Z badań przeprowadzonych przez Tavora (2014) wynika, że jeśli chodzi o rynki finansowe, istnieje krótkookresowy związek między wskaźnikiem zysku a atakiem, także w ciągu dwóch następnych dni. Im bardziej poważny jest incydent, jeśli chodzi o skutki bezpośrednie, tym silniejszy jest spadek wskaźnika. Istnieje też zależność pomiędzy siłą wpływu ataku a stopniem rozwoju gospodarczego kraju - państwa rozwijające się są bardziej poszkodowane. Do podobnych wniosków doszli też Volodin i Mikhalev (2017), zauważając, że ważny jest trend rozwoju rynku - jeśli jest on rosnący, wówczas wpływ ten jest o wiele mniejszy niż w przypadku tendencji spadkowej.

Ten ostatni fakt może być wynikiem siły gospodarczej danego kraju i jego możliwości radzenia sobie ze ściśle materialnymi skutkami ataku. Wiąże się to z możliwościami odbudowy zniszczonych obiektów i znalezieniem na nią środków (między innymi pochodzących z wypłat odszkodowań przez towarzystwa ubezpieczeniowe), a także ze znalezieniem pracowników, zarówno o odpowiednich kwalifikacjach, jak i wystarczająco odważnych lub zdeterminowanych, by podjąć pracę w miejscu, w którym niedawno zginęli inni ludzie.

Wspomniane wyżej ubezpieczenia są również czynnikiem związanym pośrednio z wpływem terroryzmu na gospodarkę. Konieczność zabezpieczenia się przed skutkami ataków podnosi wysokość składek ubezpieczeniowych, a tym samym także koszty funkcjonowania przedsiębiorstw.

Terroryzm wpływa również na wymianę handlową i napływ inwestycji. Ma to związek nie tylko z przepływami towarów i środków pieniężnych, ale też z koniecznością fizycznego przemieszczania się. Ataki w 2004 r. w Hiszpanii na dworce kolejowe czy w Rosji w 2010 r. na pociąg „Newski Ekspres” są tego przykładami. Problemem jest też zabezpieczenie systemów bankowych przed atakami hakerskimi, w wyniku których terroryści nie tylko mogą 
zdobywać środki na finasowanie swej działalności, ale też paraliżować, a co najmniej utrudniać przepływy pieniężne finansujące gospodarkę. Trudno w tym wypadku zapewnić stuprocentowe bezpieczeństwo jakiejkolwiek instytucji czy bankowi, skoro korzystanie z Internetu jest dziś powszechne i usprawnia znacząco rozwój gospodarczy. Niekiedy jest nawet mowa, że pojawi się nowy rodzaj wojen - wojny (w tym z terroryzmem) V generacji, czyli w sieci (Cegiełka, 2014). Niewątpliwie jest to czynnik, który również ma coraz silniejszy wpływ na gospodarkę, choćby w kontekście wspomnianych wyżej rosnących środków przeznaczanych przez państwa, ale też i instytucje prywatne, takie jak wielkie banki czy korporacje transnarodowe, na zapobieganie tego typu działaniom.

Transport oraz handel detaliczny również należą do sektorów najczęściej atakowanych przez organizacje terrorystyczne. Terroryści, chcąc spowodować jak największą liczbę ofiar, atakują obiekty transportowe (takie jak metro, dworce, lotniska), do których mają ułatwiony dostęp. Może to spowodować sparaliżowanie systemu bezpieczeństwa państwa, dlatego też nowoczesny system transportu musi być jak najmniej podatny na zagrożenia terrorystyczne oraz trwały z punktu widzenia ekonomicznego, socjalnego i ochrony środowiska. Należy tu również zwrócić uwagę na ekonomiczne skutki ataku na transport i jego środki. To nie tylko efekty bezpośrednie, czyli zniszczona infrastruktura i poszkodowani bezpośrednio ludzie. To również straty spowodowane $w$ innych przedsiębiorstwach przez to, że część pracowników nie dotarła do pracy i taka sytuacja może trwać dość długo. Tego typu skutki trudno jest zmierzyć i mogą wydawać się nieznaczne, jednak w dłuższym czasie należy je uwzględniać.

Handel detaliczny to drugi najczęściej atakowany sektor gospodarki. Zamachowcy uderzają nie tylko w centra handlowe czy supermarkety, ale również lokale gastronomiczne, restauracje, kluby i bary. Istnieją trzy główne przyczyny ataków terrorystycznych w tym sektorze. Po pierwsze, znaczna ich część jest skierowana przeciwko sklepom, które nie są w posiadaniu danej organizacji, zwłaszcza islamistów, czy jej zwolenników. Po drugie, terroryści na cel swoich ataków chętnie wybierają znane marki, będące symbolem świata zachodniego i kapitalizmu. Po trzecie, handel detaliczny jest dla tych grup atrakcyjnym przedmiotem ataku ze względu na możliwość spowodowania znacznych strat w ludziach, dużych utrudnień w życiu codziennym oraz skutecznego zastraszenia ludności cywilnej (Nowacki, 2015).

W tabeli 4 ukazane zostały dziedziny gospodarki, na które terroryzm miał największy wpływ w 2017 r.

Przemysł rafineryjny jest obecnie jedną z najbardziej newralgicznych części gospodarki, więc warto zwrócić uwagę, że zniszczenia w nim mają szersze oddziaływanie niż zamachy na środki transportu - w skrajnym wypadku mogą sparaliżować świat. To jednak broń obosieczna, więc terroryści dążą do zapewnienia sobie dostępu do złóż i rafinerii. Natomiast od lat nie zmienia się znaczenie handlu detalicznego na mapie terroryzmu. W porównaniu z rokiem 2015 spadł jednakże wpływ zamachów na turystykę i przedsiębiorstwa użyteczności publicznej (Nowacki, 2015).

Według szacunków przeprowadzonych przez naukowców z Cambridge i firmy ubezpieczeniowej Lloyd's, dotyczących lat 2015-25, terroryzm z ekonomicznego punktu widzenia znajduje się na 9. miejscu zagrożeń i jest w stanie zniszczyć dochód o wartości 98 mld dolarów (2,5 proc. ryzyka w omawianej dekadzie) (Jóźwik, 2016). 
Tabela 4. Dziedziny gospodarki najbardziej dotknięte przez terroryzm w 2017 r. (w \%)

\begin{tabular}{|l|c|}
\hline \multicolumn{1}{|c|}{ Dziedzina gospodarki } & Wpływ \\
\hline Przetwórstwo ropy naftowej & 33,2 \\
\hline Handel detaliczny & 11,6 \\
\hline Przetwórstwo gazu ziemnego & 8,7 \\
\hline Budownictwo & 7,52 \\
\hline Finanse & 7,51 \\
\hline Media & 7,51 \\
\hline Pozostałe & 23,96 \\
\hline
\end{tabular}

Źródło: opracowanie własne na podstawie (Aon Risk Solutions, 2017).

\section{Terroryzm w Europie}

Po roku 2001 Europa również stała się terenem licznych zamachów, zwłaszcza jej zachodnia część. Wprawdzie, jak to pokazano w tabeli 1 , nie jest rejonem o największym zagrożeniu, trudno jednak mówić, że jest bezpieczna. Terroryści atakują głównie w krajach rozwiniętych gospodarczo, choć nie tylko.

Tabela 5 pokazuje ilość ataków w krajach UE w ostatnim dziesięcioleciu. Są to ataki zarówno dokonane, jak i udaremnione.

Z powyższego zestawienia wynika, że krajami, w których najczęściej dochodzi do ataków, są Wielka Brytania, Francja i Hiszpania. W tych państwach terroryzm ma dość długą „tradycję" - ataki były przeprowadzane przez różnego rodzaju ekstremistów - prawicowych, lewicowych czy organizacje separatystyczne. Szczegółowa analiza rodzajów ataków i grup je przeprowadzających nie jest przedmiotem badań niniejszej pracy.

Warto też zauważyć, że w ostatnich latach do zamachów doszło w krajach dotychczas spokojnych - w Belgii i Niemczech. Ten ostatni kraj jest interesujący ze względu zarówno na bezpośrednie sąsiedztwo z Polską, jak i fakt, że wśród ofiar znaleźli się nasi rodacy. Oznacza to również, że bezpieczeństwo naszego kraju jest iluzoryczne, gdyż jest on narażony w stopniu porównywalnym z innymi częściami Europy. Raport MSWiA (Ministerstwo Spraw Wewnętrznych i Administracji [MSWiA], 2016) o stanie bezpieczeństwa stwierdza, że mimo podwyższonego poziomu zagrożenia zamachami terrorystycznymi na świecie, w tym także w części państw Europy Zachodniej, zagrożenie terrorystyczne w Polsce utrzymywało się w 2016 r. na stosunkowo niskim poziomie. Podobnie jak w latach ubiegłych nasz kraj pozostawał jedynie celem rezerwowym dla ewentualnych zamachów terrorystycznych, jednak widoczne wśród islamskich terrorystów zdeterminowanie do atakowania celów w państwach Unii Europejskiej wskazuje, że utrzymuje się zagrożenie dla Europy ze strony ekstremistów islamskich, co może wpłynąć także na stan bezpieczeństwa w Polsce. To ryzyko zwiększa fakt, że do Europy stale napływają emigranci z Bliskiego Wschodu i Afryki Północnej, czyli rejonów, gdzie do zamachów dochodzi najczęściej. Jak pokazują doniesienia prasowe i statystyki, wśród uchodźców ukrywają się niestety też terroryści, którzy często prowadzą akcję werbunkową w krajach europejskich, zarówno osobiście, jak i przy pomocy narzędzi komunikacji społecznej. Działania te bywają skuteczne i powodują, że do terrorystów dołączają obywatele krajów dotychczas z tego rodzaju przemocą nie kojarzonych. Szczególnie niebezpieczne są wyjazdy zradykalizowanych obywateli Unii Europejskiej, z których wielu pochodzi z rejonów objętych konfliktami zbrojnymi, w celu wzięcia udziału w walkach po stronie islamistów jako tak zwani zagraniczni bojownicy terrorystyczni, lub 
Tabela 5. Ataki terrorystyczne w UE w latach 2007-2017

\begin{tabular}{|l|c|c|c|c|c|c|c|c|c|c|c|}
\hline \multirow{2}{*}{ Kraj } & \multicolumn{9}{|c|}{ Rok } \\
\cline { 2 - 12 } & $\mathbf{2 0 0 7}$ & $\mathbf{2 0 0 8}$ & $\mathbf{2 0 0 9}$ & $\mathbf{2 0 1 0}$ & $\mathbf{2 0 1 1}$ & $\mathbf{2 0 1 2}$ & $\mathbf{2 0 1 3}$ & $\mathbf{2 0 1 4}$ & $\mathbf{2 0 1 5}$ & $\mathbf{2 0 1 6}$ & $\mathbf{2 0 1 7}$ \\
\hline ogółem & $\mathbf{5 8 1}$ & $\mathbf{4 4 1}$ & $\mathbf{2 9 4}$ & $\mathbf{2 4 9}$ & $\mathbf{1 7 4}$ & $\mathbf{2 1 9}$ & $\mathbf{1 5 2}$ & $\mathbf{1 9 9}$ & $\mathbf{2 1 1}$ & $\mathbf{1 4 2}$ & $\mathbf{2 0 5}$ \\
\hline Austria & 1 & 6 & 6 & 2 & - & - & - & - & - & - & - \\
\hline Belgia & - & - & - & - & - & 2 & - & 1 & - & 4 & 2 \\
\hline Bułgaria & - & - & - & - & - & 2 & - & - & - & - & - \\
\hline Czechy & - & - & - & 1 & - & - & - & - & - & - & - \\
\hline Dania & - & - & - & 2 & 4 & - & - & - & 2 & - & - \\
\hline Finlandia & - & - & - & - & - & - & - & - & - & - & 1 \\
\hline Francja & 267 & 147 & 95 & 84 & 85 & 125 & 63 & 52 & 73 & 23 & 54 \\
\hline Grecja & 2 & 14 & 15 & 21 & 6 & 1 & 14 & 7 & 4 & 6 & 8 \\
\hline Hiszpania & 279 & 263 & 171 & 90 & 47 & 54 & 33 & - & 25 & 10 & 16 \\
\hline Holandia & - & - & - & - & - & - & - & 18 & - & 1 & - \\
\hline Irlandia & - & 2 & - & - & - & - & - & - & - & - & - \\
\hline Niemcy & 20 & - & - & - & 1 & - & - & - & - & 5 & 2 \\
\hline Portugalia & 1 & - & - & - & - & - & - & - & - & - & - \\
\hline Szwecja & & & & 1 & - & - & - & - & - & - & 1 \\
\hline Węgry & 4 & - & 4 & - & - & - & - & - & - & - & - \\
\hline Wlk. Brytania & bd & bd & bd & 40 & 26 & 24 & 35 & 109 & 103 & 76 & 107 \\
\hline Włochy & 9 & 9 & 3 & 8 & 5 & 11 & 7 & 12 & 4 & 17 & 14 \\
\hline
\end{tabular}

Uwagi: bd-brak danych.

Źródło: opracowanie własne na podstawie (Europol, 2008, 2009, 2010, 2011, 2012, 2013, 2014, 2015, 2016, 2017, 2018).

podjęcia szkolenia terrorystycznego. Powrót takich osób do krajów pochodzenia, z uwagi na ich radykalne poglądy i zdobyte doświadczenie bojowe, stanowi realne zagrożenie przeprowadzenia ataku terrorystycznego w Europie. Problem ten dotyczy kilkutysięcznej grupy obywateli Unii Europejskiej (w szczególności z Francji, Wielkiej Brytanii i Niemiec), a także pojedynczych Polaków. Raport podkreśla, że czynnikiem, który może w przyszłości skutkować próbami podejmowania działalności terrorystycznej na terytorium Polski, pozostaje fakt, że w naszym kraju przebywają osoby z państw i regionów podwyższonego ryzyka. Ponadto geopolityczne położenie Polski i uwarunkowania prawne wynikające z członkostwa w Unii Europejskiej, w tym także przynależność do strefy Schengen, sprawiają, że Polska może pełnić dla obywateli wyżej wspomnianych państw rolę kraju tranzytowego. Przez nasze terytorium mogą oni próbować przedostać się w rejony konfliktu lub powrócić z nich, podobnie jak będący obywatelami Unii zagraniczni bojownicy terrorystyczni. Odnotowano również przypadki legalnego wjazdu na terytorium Polski osób, których rzeczywisty cel przyjazdu był niezgodny z deklarowanym (między innymi pod pretekstem udziału w szkoleniach, podjęcia nauki na polskich uczelniach, poddania się leczeniu czy też nawiązania współpracy biznesowej). Polskę wykorzystywano jedynie do wjazdu na obszar Unii Europejskiej. Ponadto pozostające w Polsce osoby objęte procedurą uchodźczą w większości przypadków korzystają z całkowitej swobody przemieszczania się, co mogą wykorzystywać w celu przedostania się do innych krajów obszaru Schengen, i często tak właśnie się dzieje.

Czynnikiem ryzyka, często przyciągającym zamachowców i mogącym wpływać szerzej na gospodarkę, jest organizacja na terytorium Polski istotnych wydarzeń międzynarodowych, które mogą zainteresować organizacje terrorystyczne. W tym kontekście należy wskazać, że 
w 2016 r. na podstawie przepisów ustawy z dnia 10 czerwca 2016 r. o działaniach antyterrorystycznych trzykrotnie wprowadzono stopień alarmowy w związku z organizacją szczytu NATO i Światowych Dni Młodzieży. W lipcu 2017 r. podczas szczytu NATO wprowadzono pierwszy stopień alarmowy (ALFA), który obowiązywał na obszarze Warszawy. Stopień alarmowy ALFA wprowadzono także podczas Światowych Dni Młodzieży - na całym terytorium państwa. Dodatkowo w związku z zagrożeniami dla cyberprzestrzeni RP podczas Światowych Dni Młodzieży wprowadzony został drugi stopień alarmowy CRP (BRAVO-CRP) (MSWiA, 2016). Oczywiście wprowadzenie tego rodzaju alertu wiąże się z dużymi kosztami.

\section{Terroryzm a handel Polski z UE i jego konkurencyjność}

Jak już wspomniano, ataki terrorystyczne mają wpływ na gospodarkę wielu krajów, zarówno tych, w których do nich dochodzi, jak i ich partnerów gospodarczych. Wiąże się to z możliwymi opóźnieniami w dostawach zamówionych towarów lub całkowitym ich zaniechaniem, jeśli przedsiębiorstwo zostanie zniszczone. Kraje, w których dochodzi do zamachów, są oceniane jako mało bezpieczne, zwłaszcza że ataków dokonuje się przede wszystkim w dużych miastach, gdzie zwykle lokują się inwestorzy ze względu na dobrze rozwiniętą infrastrukturę. Wzrost terroryzmu może zatem negatywnie wpłynąć na konkurencyjność gospodarek.

Celem niniejszej pracy jest pokazanie, czy zamachy terrorystyczne w krajach Unii wpłynęły na konkurencyjność polskiego eksportu do nich. Można sformułować hipotezę, że w przypadku krajów silnych gospodarczo terroryzm nie ma znaczącego wpływu na konkurencyjność polskiej wymiany handlowej.

Poniżej zostały przedstawione wyniki badań zmian konkurencyjności eksportu Polski do tych krajów Unii Europejskiej, w których w ostatnim dziesięcioleciu doszło do ataków terrorystycznych. Omówienie niezwykle bogatej literatury dotyczącej tej dziedziny nauki w ramach niniejszego artykułu jest niemożliwe, warto jednak wspomnieć, że szczegółowo opisano je na przykład w (Szymanik, 2004) i (Pilarska, 2017). Ponieważ konkurencyjność można definiować na wiele sposobów ${ }^{1}$ (Szymanik, 2016), na potrzeby niniejszej pracy przyjęto definicję jednoczynnikową, sformułowaną przez Hübner (1994): „...przez międzynarodową konkurencyjność gospodarki krajowej rozumie się jej konkurencyjność cenową i pozacenową, a więc atrakcyjność eksportowanych przez dany kraj towarów i usług oraz produktów będących substytutami dóbr importowanych" (s. 336).

\section{METODYKA BADAWCZA}

W niniejszej pracy, ze względu na jej ograniczony charakter, autorka skupiła się na analizie mniej zaawansowanej formy wskaźników: RCA w formie logarytmicznej oraz IIT, uzupełnionych o udziały poszczególnych państw badanej grupy w polskim handlu zagranicznym.

Wskaźnik ujawnionej przewagi komparatywnej $R C A$.

$$
R C A_{i}=\ln X_{i}-\ln M_{i}
$$

gdzie:

$X_{i}$ - wartość eksportu grupy towarowej $i$

$M_{i}$ - wartość importu grupy towarowej $i$.

\footnotetext{
${ }^{1}$ W literaturze występuje ponad 400 definicji.
} 
Wartość $R C A_{i}$ mniejsza od zera świadczy o braku, zaś RRCA $A_{i}$ większa od zera - o występowaniu ujawnionej przewagi względnej oraz o intensywności międzygałęziowego handlu i międzynarodowego podziału pracy.

$$
I I T=\left[\frac{\left(X_{i}+M_{i}\right)-\left|X_{i}-M_{i}\right|}{X_{i}+M_{i}}\right] \cdot 100
$$

Wskaźnik handlu międzygałęziowego IIT

Wartości bliskie 100\% świadczą o wysokiej intensywności wymiany i dużym podobieństwie struktur handlowych, a co za tym idzie - również wysokiej spójności ekonomicznej badanych gospodarek.

Udziały w eksporcie

$$
U=\left(X_{i} / X\right) \cdot 100
$$

gdzie:

$X_{i}$ - wartość eksportu towaru $i$. Podobnie liczony jest udział w imporcie.

\section{WYNIKI BADAŃ}

W tabeli 6 ukazano wielkość udziałów wymiany handlowej z krajami Unii, w których w ostatnim dziesięcioleciu doszło do aktów terroru.

Dane z tabeli 6 pozwalają na stwierdzenie, że mimo odnotowania w ostatnich latach zwiększonej liczby ataków terrorystycznych w niektórych krajach, takich jak Wielka Brytania, Francja czy Włochy, nie widać znaczących zmian, jeśli chodzi o ich udział w polskim handlu zagranicznym. Oznacza to, że zamachy terrorystyczne w Europie nie są ważnym czynnikiem wpływającym na handel, przynajmniej jeśli chodzi o Polskę, lecz prawdopodobnie można ten wniosek ekstrapolować na pozostałe kraje.

W tabeli 7 przedstawiono wartości wskaźników RCA i IIT dla produktów przemysłowych z grup 3,5-9 SITC. Wybrano je ze względu na znaczenie, jakie mają w polskim handlu zagranicznym oraz na fakt, że są to produkty zaawansowane technologicznie, a poprawa konkurencyjności w tych dziedzinach świadczy o rozwoju gospodarczym danego kraju. Ponadto do wytwarzania tych produktów potrzebna jest zaawansowana infrastruktura, która może być celem ataków.

Jeśli mowa o Francji, to z powyższej tabeli wynika, że im mniejsza liczba ataków, tym podobieństwo struktur gospodarek naszej i francuskiej jest mniejsze, zaś względna przewaga utrzymuje się na zbliżonym poziomie. Można zatem wnioskować, że zmniejszona liczba ataków oznacza wzmocnienie gospodarki i poprawę przewagi danego kraju, w tym przypadku Francji.

W przypadku Grecji sprawa wygląda nieco inaczej - tu zmniejszona liczba aktów terroru nie przekłada się na poprawę konkurencyjności greckiej gospodarki w stosunku do polskiej. Dzieje się tak prawdopodobnie dlatego, że większość zamachów ma podłoże polityczne, dochodzi do nich głównie w Atenach i nie dotykają one wrażliwej infrastruktury przemysłowej. Zwiększenie podobieństwa struktur polskiego i greckiego handlu nie powinno jednak cieszyć, gdyż oznacza to, że polska gospodarka staje się coraz bardziej podobna do greckiej, a ta ostatnia nie zalicza się do najsilniejszych i najlepiej rozwiniętych. 
Tabela 6. Udział danego kraju w wymianie handlowej Polski z krajami Unii, w których odnotowano ataki terrorystyczne ( $w \%$, wymiana $z$ UE $=100 \%$ )

\begin{tabular}{|c|c|c|c|c|c|c|c|c|c|c|c|}
\hline \multicolumn{12}{|c|}{ Udziały w imporcie } \\
\hline \multirow{2}{*}{ Kraj } & \multicolumn{11}{|c|}{ Rok } \\
\hline & 2007 & 2008 & 2009 & 2010 & 2011 & 2012 & 2013 & 2014 & 2015 & 2016 & 2017 \\
\hline Austria & 2,6 & 2,8 & 2,8 & 2,8 & 3,1 & 3 & 3 & 3 & 3 & 2,7 & 2,8 \\
\hline Belgia & 3,9 & 3,8 & 3,8 & 4 & 3,7 & 3,9 & 3,9 & 4,1 & 4,1 & 4,3 & 4,2 \\
\hline Bułgaria & 0,3 & 0,3 & 0,3 & 0,3 & 0,4 & 0,4 & 0,4 & 0,4 & 0,5 & 0,5 & 0,5 \\
\hline Czechy & 5,4 & 5,8 & 5,8 & 6,4 & 6,2 & 6,4 & 6,3 & 6,1 & 5,8 & 5,9 & 6 \\
\hline Dania & 2 & 2 & 2,2 & 2,1 & 2,2 & 2 & 2,1 & 2,1 & 2,1 & 1,9 & 2 \\
\hline Finlandia & 2 & 2,4 & 2,1 & 1,7 & 1,7 & 1,5 & 1,4 & 1,6 & 1,4 & 1,3 & 1,3 \\
\hline Francja & 8 & 7,6 & 7,4 & 7,3 & 7 & 6,8 & 6,5 & 6,3 & 6,2 & 6,5 & 6,4 \\
\hline Grecja & 0,3 & 0,3 & 0,3 & 0,3 & 0,4 & 0,3 & 0,3 & 0,3 & 0,4 & 0,4 & 0,4 \\
\hline Hiszpania & 3,3 & 3,5 & 3,6 & 3,4 & 3,3 & 3,6 & 3,7 & 3,4 & 3,7 & 3,7 & 3,8 \\
\hline Holandia & 5,3 & 5,6 & 5,9 & 6,2 & 6,3 & 6,8 & 6,6 & 6,4 & 6,4 & 6,3 & 6,3 \\
\hline Irlandia & 0,9 & 1,1 & 1,1 & 1,1 & 0,9 & 1 & 1,1 & 1,2 & 1,4 & 1,4 & 1,2 \\
\hline Niemcy & 37,5 & 37,1 & 36,2 & 36,8 & 37,4 & 37,1 & 37 & 37,3 & 38,1 & 38 & 38,3 \\
\hline Portugalia & 0,4 & 0,4 & 0,4 & 0,4 & 0,4 & 0,5 & 0,5 & 0,5 & 0,5 & 0,5 & 0,6 \\
\hline Szwecja & 3,4 & 3,3 & 3 & 3,2 & 3,4 & 3,3 & 3,2 & 3,1 & 3,1 & 2,8 & 3,2 \\
\hline Węgry & 3,3 & 2,9 & 3 & 2,9 & 2,9 & 2,8 & 2,8 & 2,7 & 2,7 & 2,9 & 2,9 \\
\hline Wlk. Brytania & 4,8 & 4,6 & 4,8 & 4,6 & 4,4 & 4,2 & 4,5 & 4,4 & 4,5 & 4,2 & 4 \\
\hline Włochy & 10,7 & 10,5 & 11 & 9,6 & 9 & 9,1 & 9,1 & 9,6 & 9 & 9,1 & 8,8 \\
\hline \multicolumn{12}{|c|}{ Udziały w eksporcie } \\
\hline \multirow{2}{*}{ Kraj } & \multicolumn{11}{|c|}{$\begin{array}{r}\text { Rok } \\
\end{array}$} \\
\hline & 2007 & 2008 & 2009 & 2010 & 2011 & 2012 & 2013 & 2014 & 2015 & 2016 & 2017 \\
\hline Austria & 2,4 & 2,5 & 2,4 & 2,4 & 2,5 & 2,5 & 2,3 & 2,2 & 2,2 & 2,2 & 2,4 \\
\hline Belgia & 3,4 & 3,3 & 3 & 3 & 3 & 2,7 & 2,9 & 2,9 & 2,7 & 2,8 & 2,8 \\
\hline Bułgaria & 0,5 & 0,6 & 0,4 & 0,4 & 0,4 & 0,5 & 0,6 & 0,6 & 0,6 & 0,7 & 0,7 \\
\hline Czechy & 5,4 & 7,3 & 7,3 & 7,6 & 8 & 8,3 & 8,3 & 8,3 & 8,4 & 8,2 & 8 \\
\hline Dania & 2,4 & 2,5 & 2,3 & 2,4 & 2,4 & 2,2 & 2,3 & 2,1 & 2,1 & 2,2 & 2,3 \\
\hline Finlandia & 0,9 & 1,1 & 1 & 0,9 & 1 & 1 & 1 & 1,1 & 1 & 1 & 1 \\
\hline Francja & 7,7 & 8 & 8,7 & 8,6 & 7,9 & 7,7 & 7,5 & 7,2 & 7 & 6,9 & 7 \\
\hline Grecja & 0,5 & 0,7 & 0,8 & 0,5 & 0,6 & 0,5 & 0,5 & 0,5 & 0,5 & 0,5 & 0,5 \\
\hline Hiszpania & 3,7 & 3,2 & 3,3 & 3,4 & 3,1 & 2,6 & 3 & 3,2 & 3,3 & 3,4 & 3,4 \\
\hline Holandia & 4,9 & 5,2 & 5,3 & 5,5 & 5,6 & 5,9 & 5,3 & 5,4 & 5,6 & 5,6 & 5,5 \\
\hline \begin{tabular}{|l|} 
Irlandia \\
\end{tabular} & 0,5 & 0,6 & 0,5 & 0,5 & 0,4 & 0,4 & 0,4 & 0,4 & 0,4 & 0,5 & 0,5 \\
\hline Niemcy & 32,8 & 32,2 & 32,8 & 33 & 33,4 & 33,1 & 33,4 & 34 & 34,1 & 34,3 & 34,3 \\
\hline Portugalia & 0,4 & 0,4 & 0,5 & 0,5 & 0,4 & 0,4 & 0,4 & 0,5 & 0,5 & 0,5 & 0,5 \\
\hline Szwecja & 4,1 & 4,1 & 3,4 & 3,7 & 3,7 & 3,5 & 3,6 & 3,7 & 3,5 & 3,6 & 3,5 \\
\hline Węgry & 3,7 & 3,6 & 3,4 & 3,6 & 3,3 & 3,2 & 3,4 & 3,4 & 3,4 & 3,3 & 3,3 \\
\hline Wlk. Brytania & 7,5 & 7,4 & 8 & 7,9 & 8,3 & 8,9 & 8,7 & 8,2 & 8,5 & 8,3 & 8 \\
\hline Włochy & 8,4 & 7,7 & 8,6 & 7,5 & 6,8 & 6,4 & 5,8 & 5,9 & 6,1 & 6 & 6,1 \\
\hline
\end{tabular}


Tabela 7. Zbiorcze wartości wskaźników RCA i IIT dla grup 3,5-9 dla lat 2007-2017

\begin{tabular}{|c|c|c|c|c|c|c|c|c|c|c|c|}
\hline \multicolumn{12}{|c|}{ Wskaźniki RCA } \\
\hline \multirow{2}{*}{ Kraj } & \multicolumn{11}{|c|}{ Rok } \\
\hline & 2007 & 2008 & 2009 & 2010 & 2011 & 2012 & 2013 & 2014 & 2015 & 2016 & 2017 \\
\hline Austria & $-0,15$ & $-0,14$ & $-0,06$ & $-0,03$ & $-0,14$ & $-0,29$ & $-0,1$ & 0,3 & $-0,06$ & $-0,01$ & 0,1 \\
\hline Belgia & $-0,17$ & $-0,18$ & $-0,06$ & $-0,14$ & $-0,06$ & $-0,01$ & $-1,02$ & $-0,02$ & $-0,15$ & $-0,18$ & $-0,16$ \\
\hline Bułgaria & 0,6 & 0,52 & 0,57 & 0,35 & 0,04 & 1,35 & 0,5 & 0,5 & 0,41 & 0,53 & 0,61 \\
\hline Czechy & 0,28 & 0,24 & 0,24 & 0,32 & 0,38 & 0,45 & 0,47 & 0,47 & 0,62 & 0,59 & 0,58 \\
\hline Dania & 0,36 & 0,45 & 0,43 & 0,54 & 0,42 & 0,54 & 0,56 & 0,56 & 0,51 & 0,74 & 0,56 \\
\hline Finlandia & $-0,85$ & $-0,82$ & $-0,71$ & $-0,61$ & $-0,55$ & $-0,36$ & $-0,17$ & $-0,17$ & $-0,18$ & $-0,06$ & 0,01 \\
\hline Francja & $-0,01$ & 0,12 & 0,3 & 0,31 & 0,24 & 0,28 & 0,32 & 0,32 & 0,32 & \begin{tabular}{|l|}
0,3 \\
\end{tabular} & 0,35 \\
\hline Grecja & 0,93 & 1,28 & 1,5 & 1,15 & 0,68 & 0,75 & 0,75 & 0,75 & 0,62 & 0,71 & 0,64 \\
\hline Hiszpania & 0,3 & 0,1 & 0,22 & 0,9 & 0,26 & 0,03 & 0,17 & 0,17 & 0,31 & 0,53 & 0,24 \\
\hline Holandia & $-0,02$ & $-0,01$ & 0,11 & 0,13 & 0,11 & 0,12 & 0,05 & 0,05 & 0,2 & 0,25 & 0,16 \\
\hline Irlandia & $-0,69$ & $-0,7$ & $-0,81$ & $-0,77$ & $-0,83$ & $-1,04$ & $-0,99$ & $-0,99$ & $-1,1$ & $-0,98$ & $-0,69$ \\
\hline Niemcy & $-0,16$ & $-0,17$ & 0,04 & 0,04 & 0,02 & 0,07 & 0,09 & 0,09 & 0,15 & 0,15 & 0,16 \\
\hline Portugalia & 0,21 & 0,14 & 0,3 & 0,34 & 0,23 & 0,14 & 0,18 & 0,18 & 0,39 & 0,42 & 0,29 \\
\hline Szwecja & 0,21 & 0,24 & 0,27 & 0,35 & 0,29 & 0,25 & 0,36 & 0,4 & 0,43 & 0,58 & 0,41 \\
\hline Węgry & 0,11 & 0,19 & 0,19 & 0,32 & 0,24 & 0,31 & 0,4 & 0,4 & 0,49 & 0,38 & 0,41 \\
\hline Wlk. Brytania & 0,42 & 0,46 & 0,67 & 0,71 & 0,79 & 0,93 & 0,85 & 0,85 & 0,86 & 1,05 & 0,95 \\
\hline Włochy & $-0,24$ & $-0,32$ & $-0,14$ & $-0,13$ & $-0,18$ & $-0,23$ & $-0,34$ & $-0,34$ & $-0,22$ & $-0,24$ & $-0,09$ \\
\hline \multicolumn{12}{|c|}{ Wskaźniki IIT } \\
\hline \multirow{2}{*}{ Kraj } & \multicolumn{11}{|c|}{ Rok } \\
\hline & 2007 & 2008 & 2009 & 2010 & 2011 & 2012 & 2013 & 2014 & 2015 & 2016 & 2017 \\
\hline Austria & 92,4 & 92,8 & 92,8 & 98,6 & 93 & 89,5 & 95 & 81,1 & 97 & 99,8 & 94,9 \\
\hline Belgia & 91,7 & 91,1 & 91,1 & 93 & 97,1 & 95,3 & 99,3 & 96,8 & 92,6 & 90,8 & 91,9 \\
\hline Bułgaria & 71 & 74,5 & 72,1 & 82,6 & 98 & 41,1 & 75,4 & 83,2 & 79,8 & 74,1 & 70,4 \\
\hline Czechy & 86,2 & 87,8 & 94,3 & 84 & 81,1 & 77,7 & 76,9 & 96,8 & 70,2 & 71,4 & 71,9 \\
\hline \begin{tabular}{|l|} 
Dania \\
\end{tabular} & 82,4 & 77,9 & 77,9 & 73,7 & 79,2 & 73,4 & 72,9 & 70,8 & 75 & 64,4 & 72,6 \\
\hline Finlandia & 59,9 & 61 & 61,01 & 70,6 & 73,2 & 82 & 91,3 & 89 & 90,8 & 97 & 99,6 \\
\hline Francja & 99,4 & 94,1 & 94,1 & 84,9 & 88,1 & 86,1 & 84,3 & 85 & 84,1 & 85,1 & 82,5 \\
\hline Grecja & 56,5 & 43,6 & 43,6 & 48,2 & 67,2 & 64,4 & 64,1 & 64,1 & 70,2 & 65,8 & 69 \\
\hline Hiszpania & 85,2 & 95,2 & 95,2 & 57,9 & 86,9 & 98,5 & 91,3 & 83,5 & 84,5 & 82,6 & 88,1 \\
\hline Holandia & 99,1 & 99,6 & 99,6 & 93,6 & 94,7 & 94,2 & 97,4 & 92,7 & 90,2 & 87,8 & 92 \\
\hline Irlandia & 67 & 66,2 & 66,2 & 63,2 & 60,8 & 52,1 & 54,2 & 52,1 & 50 & 54,7 & 66,7 \\
\hline Niemcy & 92,1 & 91,7 & 91,7 & 98,3 & 99 & 96,8 & 95,4 & 93,8 & 92,7 & 92,5 & 92,1 \\
\hline Portugalia & 89,6 & 92,9 & 92,9 & 83,2 & 88,7 & 92,6 & 91,3 & 86,4 & 81 & 79,6 & 85,5 \\
\hline Szwecja & 89,7 & 87,9 & 87,9 & 82,9 & 85,7 & 87,4 & 82,2 & 77,2 & 79 & 71,7 & 79,9 \\
\hline Węgry & 94,5 & 90,4 & 90,4 & 83,9 & 88,3 & 84,9 & 80,1 & 52,1 & 76,1 & 81,0 & 79,8 \\
\hline Wlk. Brytania & 79,4 & 77,3 & 77,3 & 66,1 & 62,5 & 56,6 & 60 & 60,4 & 59,3 & 51,8 & 55,7 \\
\hline Włochy & 88,1 & 84 & 83,9 & 93,5 & 90,9 & 88,7 & 83,1 & 82,2 & 89,2 & 88,1 & 95,3 \\
\hline
\end{tabular}

Źródło: jak w tabeli 6.

W odniesieniu do Hiszpanii trudno mówić o zaobserwowaniu zależności pomiędzy zmianą konkurencyjności polskiego eksportu a liczbą zamachów terrorystycznych. Wynika 
to prawdopodobnie z rozmiarów gospodarki hiszpańskiej i większego wpływu innych czynników, takich jak wciąż odczuwalne skutki kryzysu.

W handlu z Wielką Brytanią względna przewaga Polski nieznacznie rośnie w badanym okresie, mimo że podobnie rzecz się ma w odniesieniu do liczby zamachów. Podobieństwo struktur gospodarek niestety systematycznie maleje, co nie jest korzystnym prognostykiem dla polskiej gospodarki, bo świadczy o zmniejszaniu się jej konkurencyjności.

Jeśli chodzi o Włochy, to kraj ten od lat utrzymuje nieznaczną względną przewagę w handlu z Polską, a podobieństwo struktur wymiany obu krajów zmienia się, lecz nie widać zależności pomiędzy tymi zmianami a liczbą ataków, nieznaczną w porównaniu z wielkością kraju. Podobnie jak w przypadku Hiszpanii można wnioskować, że znacznie większy wpływ na zmiany konkurencyjności mają inne czynniki niż terroryzm.

Z powyższej analizy wynika, że w przypadku handlu Polski z krajami Unii Europejskiej nie można odnotować zależności pomiędzy ilością przeprowadzonych ataków a ich wpływem na konkurencyjność polskiego eksportu, która nie poprawiła się w badanych krajach w sposób znaczący, co potwierdza postawioną hipotezę. Jest to prawdopodobnie skutek tego, że tych ataków nie notuje się zbyt wiele, a ogólny poziom bezpieczeństwa w badanych krajach jest wysoki. Dodatkowo kraje te są dobrze rozwinięte gospodarczo, a ich systemy polityczne są stabilne, przynajmniej w porównaniu z krajami Afryki Północnej i Bliskiego Wschodu, w których często można mówić o wojnie domowej. Taka stabilność i dobrze rozwinięte systemy ubezpieczeniowe sprawiają, że niwelowanie skutków ataków jest dość sprawne i nie powoduje większych zakłóceń w funkcjonowaniu gospodarki. Ataki mają jedynie krótkotrwały i przejściowy wpływ, nie znajdujący odzwierciedlenia w wynikach zmian konkurencyjności polskiego eksportu.

\section{PODSUMOWANIE}

Powyższa analiza pozwala na wysnucie kilku wniosków.

Pierwszy z nich dotyczy ułatwień dla podróżujących. W erze powszechnych podróży takie ułatwienia są konieczne, by gospodarki mogły się lepiej rozwijać. Skrócenie kontroli poprawia komfort podróżnych, ale sprzyja przemieszczaniu się również terrorystów, których trudno wyeliminować, zwłaszcza że wielu z nich prowadzi swą działalność dopiero po przybyciu na miejsce.

Drugi wniosek dotyczy spraw ekonomicznych. Mimo że terroryzm ma bezpośredni, acz wybiórczy, wpływ na gospodarkę (dotyczy to zwłaszcza giełdy), brak jest dokładnych danych statystycznych w ogólnodostępnych źródłach dotyczących strat powodowanych przez ataki terrorystyczne. Do badań przydatne byłoby wprowadzenie podawania takich informacji (Engene, 2007) ${ }^{2}$, stąd propozycja dla urzędów statystycznych, by zaczęły je podawać, gdyż prawdopodobnie problem będzie narastał, a należy go zbadać, aby opracować dobrą strategię łagodzenia skutków gospodarczych ataków. W Polsce ubezpieczenie przeciwko skutkom zamachów znajduje się w ofercie wszystkich towarzystw. Nie jest stosowane standardowo, lecz pojawia się coraz częściej, na przykład w czasie Dni Młodzieży w Krakowie w 2016 r. wiele podmiotów rozszerzyło zakres swego ubezpieczenia o ten rodzaj ochrony. Oznacza to, że coraz powszechniej uznaje się tę groźbę za realną i uwzględnia się jej skutki gospodarcze.

\footnotetext{
${ }^{2}$ Ten postulat nie jest nowy. Zgłasza go wielu badaczy, aczkolwiek zwracają uwagę na różne rodzaje potrzebnych danych.
} 
Należy zauważyć, że zamachy silnie oddziałują nie tylko na gospodarki tych krajów, które są nimi bezpośrednio dotknięte, lecz także na inne, co wynika z coraz silniejszych powiązań między nimi, zarówno gospodarczych, jak i technologicznych, a także politycznych.

Jeśli chodzi o handel pomiędzy Polską a krajami Unii, nie ma zauważalnego jednoznacznego związku między atakami terrorystycznymi a ich wpływem na konkurencyjność.

Na podstawie ogólnodostępnych danych, po przeprowadzeniu wyżej przedstawionych badań, nie można stwierdzić wyraźnego wpływu terroryzmu na zmiany konkurencyjności polskiego eksportu do krajów europejskich nim dotkniętych, choć można domniemywać, że powinien wystąpić z uwagi na osłabienie gospodarek przez akty terroru. Wynika to zapewne z faktu, że kraje unijne, w których miała miejsce największa liczba ataków, są krajami silnymi ekonomicznie, o dobrze rozwiniętym systemie przeciwdziałania atakom i łagodzenia ich skutków, natomiast inaczej rzecz wygląda w tych, które terroryzm dotyka najsilniej - Afryki Północnej czy Afganistanu. Tam jednak w grę wchodzi cały szereg czynników, które nie są omawiane w niniejszej pracy. Jak już wspomniano, brak danych statystycznych, które pozwoliłyby bezpośrednio potwierdzić ten wniosek, postulowane jest zatem najpierw rozszerzenie sposobu ich gromadzenia i udostępniania, by można było w przyszłości prowadzić dokładniejsze badania, gdyż problem terroryzmu nie zostanie wyeliminowany, a jego skutki ekonomiczne są ważne zwłaszcza dla krajów mniej rozwiniętych gospodarczo.

\section{LITERATURA}

Abadie, A., Gardeazabal, J. (2005). Terrorism and the world economy. Pozyskano 20.05.2019 z https://addi.ehu.es/bitstream/handle/10810/6734/wp2005-19.pdf?sequence=1\&isAllowed=y

Aon Risk Solutions (2017). 2017 Risk Maps Aon's guide to Political Risk, Terrorism \& Political Violence. Pozyskano 11.05.2019 z https://www.aon.com/poland/attachments/risk/Risk\%20 Map\%20Brochure\%202017_w_LOGOS.pdf

Berman, E. (2009). Radical, Religious and Violent. The New Economics of Terrorism. London: The MIT Press.

Bolechów, B. (2003). Terroryzm w świecie podwubiegunowym. Toruń: Wydawnictwo Adam Marszałek.

Cegiełka, R. (2014). Terroryzm i bezpieczeństwo ekonomiczne. Wybrane zagadnienia. Warszawa: Agencja Wydawnicza Synergy.

Cegiełka, R. (2015). Zagrożenie terroryzmem. Poczucie bezpieczeństwa na poczq̨tku XXI wieku oraz wpływ terroryzmu na procesy gospodarcze w wymiarach mikro i makro. Warszawa: Agencja Wydawnicza Synergy.

Engene, J. O. (2007). Five Decades of Terrorism in Europe: The TWEED Dataset. Journal of Peace Research, 44(1), 109-121.

Europol (2008). European Union Terrorism Situation and Trend Report 2008.

Europol (2009). European Union Terrorism Situation and Trend Report 2009.

Europol (2010). European Union Terrorism Situation and Trend Report 2010.

Europol (2011). European Union Terrorism Situation and Trend Report 2011.

Europol (2012). European Union Terrorism Situation and Trend Report 2012.

Europol (2013). European Union Terrorism Situation and Trend Report 2013.

Europol (2014). European Union Terrorism Situation and Trend Report 2014.

Europol (2015). European Union Terrorism Situation and Trend Report 2015. 
Europol (2016). European Union Terrorism Situation and Trend Report 2016.

Europol (2017). European Union Terrorism Situation and Trend Report 2017.

Europol (2018). European Union Terrorism Situation and Trend Report 2018.

Fiszer, J. M. (2012). Terroryzm jako zagrożenie dla bezpieczeństwa euroatlantyckiego i nowego ładu międzynarodowego. Myśl Ekonomiczna i Polityczna, 3(38), 155-187.

Gold, D. (2003). Economics of Terrorism. Pozyskano 12.05.2019 z https://www.files.ethz.ch/isn/ 10698/doc_10729_290_en.pdf

GUS (2008). Rocznik statystyczny handlu zagranicznego. Warszawa: GUS.

GUS (2009). Rocznik statystyczny handlu zagranicznego. Warszawa: GUS.

GUS (2010). Rocznik statystyczny handlu zagranicznego. Warszawa: GUS.

GUS (2011). Rocznik statystyczny handlu zagranicznego. Warszawa: GUS.

GUS (2012). Rocznik statystyczny handlu zagranicznego. Warszawa: GUS.

GUS (2013). Rocznik statystyczny handlu zagranicznego. Warszawa: GUS.

GUS (2014). Rocznik statystyczny handlu zagranicznego. Warszawa: GUS.

GUS (2015). Rocznik statystyczny handlu zagranicznego. Warszawa: GUS.

GUS (2016). Rocznik statystyczny handlu zagranicznego. Warszawa: GUS.

GUS (2017). Rocznik statystyczny handlu zagranicznego. Warszawa: GUS.

GUS (2018). Rocznik statystyczny handlu zagranicznego. Warszawa: GUS.

Howard, R. (2002). Understanding Al Quaeda's Application of the New Terrorism - the Key to Victory in the Current Campaign. W: R. Howard, R. Sawyer (Eds.), Terrorism and Counterterrorism. Understanding the New Security Environment (ss. 189-191). Guilford: McGraw Hill.

Hübner, D. (1994). Międzynarodowa konkurencyjność gospodarki a strategia rozwoju. Ekonomista, 3, 335-349.

Institute for Economic \& Peace (2018a). Global Terrorism Index 2018. Pozyskano 29.04.2019 z http://visionofhumanity.org/app/uploads/2018/12/Global-Terrorism-Index-2018-1.pdf

Institute for Economics \& Pace (2018b). The Economic Value of Pace 2018. Pozyskano 10.05.2019 $\mathrm{z}$ http://economicsandpeace.org/wp-content/uploads/2018/11/Economic-Value-of-Peace-2018.pdf

Jóźwik, T. (2016). Terroryzm - niedoszacowane ryzyko. Forbes, 1, 16.

Kacperska, E. (2017). Terroryzm międzynarodowy jako problem globalny współczesnej gospodarki. Zeszyty Naukowe Szkoły Głównej Gospodarstwa Wiejskiego, 120, 17-31.

Koran (1986). Warszawa: PIW.

Łuczkowska, M., (2013). Piractwo i terroryzm morski jako zagrożenia transportu morskiego. Logistyka, 1, 734-742.

Michalczuk-Ouerghi, K., Dłużewska, A. (2018). Wpływ terroryzmu i islamizacji na gospodarkę turystyczną Tunezji. Turystyka Kulturowa, 6, 58-79.

Ministerstwo Przedsiębiorczości i Technologii (2019). Sri Lanka. Informacja o stosunkach gospodarczych z Polską. Pozyskano 29.05.2019 z https://www.gov.pl/documents/910151/911704/DHM_Sri_ Lanka_20190304.pdf/4670c013-305f-06a0-51a2-efcd84c9b2cf

MSWiA (2016). Raport o stanie bezpieczeństwa w Polsce w 2016 r. Pozyskano 11.05.2019 z https://archiwumbip.mswia.gov.pl/bip/raport-o-stanie-bezpie/18405, Raport-o-stanie-bezpieczenstwa.html/ 
National Consortium for the Study of Terrorism and Responses to Terrorism, Global Terrorism database, Pozyskano 11.05.2019 z https://www.start.umd.edu/gtd/search/Results.aspx?search= 2009\&sa. $x=56 \&$ sa. $y=9$.

National Consortium for the Study of Terrorism and Responses to Terrorism (2017). Global Terrorism in 2017. Pozyskano 11.05.2019 z https://www.start.umd.edu/pubs/START_GTD_Overview2017_July2018.pdf

Nowacki, G. (2015). Zagrożenia terrorystyczne na świecie. Nierówności Społeczne a Wzrost Gospodarczy, 44 (4), 407-432.

Nowa encyklopedia powszechna (1997). Warszawa: PWN.

Pilarska, Cz. (2017). Międzynarodowa konkurencyjność gospodarki polskiej na tle nowych krajów członkowskich Unii Europejskiej. Kraków: Wydawnictwo Uniwersytetu Ekonomicznego.

Rada Europejska (2005). Strategia UE w dziedzinie walki z terroryzmem z 15 grudnia 2005 r. Pozyskano 10.05.2019 z https://www.consilium.europa.eu/pl/policies/fight-against-terrorism/eu-strategy

Szubrycht, T., Rokiciński, K. (2006). Gospodarka morska w świetle wybranych zagrożeń współczesnego świata. Gdynia: Akademia Marynarki Wojennej.

Szymanik, E. (2004). Konkurencyjność eksportu na przykładzie wymiany Polski z krajami Unii Europejskiej. Kraków: Krakowska Szkoła Wyższa im. Andrzeja Frycza Modrzewskiego.

Szymanik, E. (2016). Konkurencyjność przedsiębiorstw - główne aspekty. Zeszyty Naukowe Uniwersytetu Ekonomicznego w Krakowie, 5(953), 107-123.

Tavor, T. (2014). The effect of terror incidents on the yield of index markets for developing and developed market. Economy \& Business, 8, 1148-1153.

Volodin, S.N., Mikhalev, A.G. (2017). Analyzing the Impact of Terrorist Attacks on Stock Index Dynamics. Digest Finance, 22(2), 208-220.

Walewska, D. (2019, kwiecień). Turystyczny exodus ze Sri Lanki. Rzeczpospolita. Pozyskano z https://www.rp.pl/Biznes/304229982-Turystyczny-exodus-ze-Sri-Lanki.html

Wojciechowski, S. (2011). Terroryzm na poczq̨tku XXI wieku. Pojęcie, istota i przyczyny zjawiska. Bydgoszcz - Poznań: Oficyna Wydawnicza Branta. 


\section{Tytuł i abstrakt w języku angielskim}

\section{Terrorism vs. competitiveness of foreign trade between Poland and EU countries}

The article shows the problem of the world terrorism and its impact on the economies of the countries which are suffering on it. The author analysed potential results of terrorism for the economies competitiveness, especially for the EU countries, using RCA and IIT indicators. It was researched if terrorist's attacks had influenced on the change of Polish export competitiveness in the intra-EU trade. Results shows that even if terrorism had an impact on the economy competitiveness in a long period but its force depends on the economy condition and is connected with the security system and in the case of Poland this impact is shown at the very low level.

Keywords: $\quad$ terrorism; competitiveness; European Union; Polish foreign trade; export JEL codes: $\quad$ E23, E60, F10, F23, H56

\section{Autor}

\section{Ewa Szymanik}

Doktor nauk ekonomicznych, Uniwersytet Ekonomiczny w Krakowie. Zainteresowania: konkurencyjność gospodarek, wymiana handlowa krajów europejskich, szczególnie wewnątrz UE, problemy krajów strefy euro.

Adres do korespondencji: Dr Ewa Szymanik, Uniwersytet Ekonomiczny w Krakowie, ul. Rakowicka 27, 31-510 Kraków, e-mail: szymanie@uek.krakow.pl

ORCID (i) http://orcid.org/0000-0002-9049-9436

\section{Prawa autorskie}

Ten artykuł został opublikowany na warunkach Creative Commons Uznanie autorstwa - Bez utworów zależnych (CC BY-ND 4.0 License) http://creativecommons.org/licenses/by-nd/4.0/

Publikacja została wydana przez Uniwersytet Ekonomiczny w Krakowie 
